\title{
U-PB GEOCHRONOLOGY OF IGNEOUS AND DETRITAL ZIRCON SAMPLES FROM THE TOK RIVER AREA, EASTERN ALASKA RANGE, AND TALKEETNA MOUNTAINS, ALASKA
}

Christopher S. Holm-Denoma, Karri R. Sicard, and Evan Twelker

Raw Data File 2020-3

This report has not been reviewed for technical content or for conformity to the editorial standards of DGGS.

2020

STATE OF ALASKA

DEPARTMENT OF NATURAL RESOURCES

DIVISION OF GEOLOGICAL \& GEOPHYSICAL SURVEYS
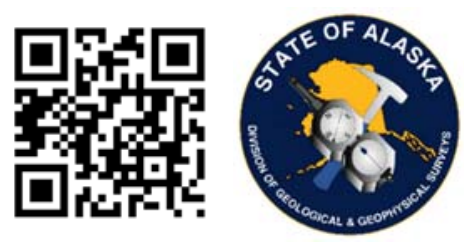
STATE OF ALASKA

Mike Dunleavy, Governor

\section{DEPARTMENT OF NATURAL RESOURCES}

Corri A. Feige, Commissioner

\section{DIVISION OF GEOLOGICAL \& GEOPHYSICAL SURVEYS}

Steve Masterman, State Geologist \& Director

Publications produced by the Division of Geological \& Geophysical Surveys are available to download from the DGGS website (dggs.alaska.gov). Publications on hard-copy or digital media can be examined or purchased in the Fairbanks office:

\section{Alaska Division of Geological \& Geophysical Surveys (DGGS)}

3354 College Road | Fairbanks, Alaska 99709-3707

Phone: 907.451.5010 | Fax 907.451.5050

dggspubs@alaska.gov $\mid$ dggs.alaska.gov

\section{DGGS publications are also available at:}

Alaska State Library, Historical

Collections \& Talking Book Center

395 Whittier Street

Juneau, Alaska 99801

Alaska Resource Library and

Information Services (ARLIS)

3150 C Street, Suite 100

Anchorage, Alaska 99503

\section{Suggested citation:}

Holm-Denoma, C.S., Sicard, K.R., and Twelker, Evan, 2020, U-Pb geochronology of igneous and detrital zircon samples from the Tok River area, eastern Alaska Range, and Talkeetna Mountains, Alaska: Alaska Division of Geological \& Geophysical Surveys Raw Data File 20203, 20 p. http://doi.org/10.14509/30439
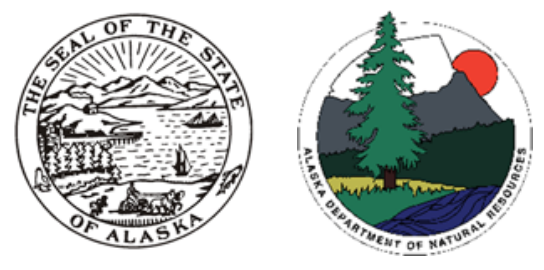


\title{
U-PB GEOCHRONOLOGY OF IGNEOUS AND DETRITAL ZIRCON SAMPLES FROM THE TOK RIVER AREA, EASTERN ALASKA RANGE, AND TALKEETNA MOUNTAINS, ALASKA
}

\author{
Christopher S. Holm-Denoma' ${ }^{1}$ Karri R. Sicard², and Evan Twelker ${ }^{2}$
}

\section{INTRODUCTION}

This Alaska Division of Geological \& Geophysical Surveys (DGGS) Raw Data File presents U-Pb zircon geochronology results from igneous, meta-igneous, and metasedimentary rocks collected during the Tok River and Wrangellia geologic mapping projects in the eastern Alaska Range and the northwestern Talkeetna Mountains, Alaska. The purpose of these analyses is to better constrain the age of select geologic units encountered during the mapping projects.

The Tok River geologic mapping project comprised the Tanacross A-5 and A-6 quadrangles. DGGS conducted fieldwork for this project during the 2015 and 2016 field seasons, and the map was published in 2017 (Sicard and others, 2017). Most of the area is underlain by Mississippian-Devonian age, greenschist- to amphibolite-facies metamorphic rocks having marine sedimentary and volcanic protoliths. These rocks are of economic interest because they host Devonian volcanogenic massive sulfide (VMS) deposits of the Delta mineral belt in the adjacent Mount Hayes A-1 Quadrangle (Dashevsky and others, 2003), as well as the lessexplored, sediment-hosted base metal prospects of the Eagle Trend in the Tanacross A-6 Quadrangle (Twelker and others, in press). Numerous sill-form(?) bodies of metamorphosed Triassic(?) gabbro intrude the Paleozoic metamorphic rocks. Following metamorphic cooling in the Early Cretaceous (Benowitz and others, 2017), a series of Late Cretaceous to Paleogene dikes and stocks of intermediate composition intruded the area. Some of these localize intrusion-related mineralization such as the Peak gold-copper-silver skarn deposit northeast of the map area and the Hona (also known as Noah) intrusion-related gold prospect within the map area (Twelker and others, in press). Illig and Newberry (2015) suggest the Peak deposit may be part of the Late Cretaceous Casino porphyry belt.

A series of northeast-oriented high-angle faults cut the Tok River area; mapping suggests these faults have a combination of left-lateral and normal offsets (Sicard and others, 2017). Activity on these structures is likely Paleogene and possibly younger. Structurally controlled gold prospects of Tanacross A-6 Quadrangle, known as the White Gold trend, may be related to this series of structures (Twelker and others, in press).

The 2013-2015 DGGS Wrangellia project investigated the geology and mineral potential of the Wrangellia terrane in the Talkeetna Mountains and eastern Alaska Range, where recent exploration activity

\footnotetext{
${ }^{1}$ U.S. Geological Survey, Geology, Geophysics and Geochemistry Science Center, Denver, Colorado 80225-0046; cholm-denoma@usgs.gov

${ }^{2}$ Alaska Division of Geological \& Geophysical Surveys, 3354 College Road, Fairbanks, Alaska 99709-3707; evan.twelker@alaska.gov
} 
has targeted nickel, copper, and platinum-group-element mineralization hosted by Late Triassic maficultramafic complexes, metasediment-hosted copper, porphyry copper-gold-molybdenum porphyry, and orogenic gold systems. The DGGS Wrangellia project included compilation and refinement of existing geologic maps of the area, new targeted geologic mapping and geochemical sampling, and collection of new geochronologic data to answer key geologic questions. This Raw Data File reports $\mathrm{U}-\mathrm{Pb}$ results for two granitic rocks and one metasedimentary rock. The results presented here represent significant revisions to the previous understanding of the age of these intrusions.

The samples were submitted to the U.S. Geological Survey, Geology, Geophysics, and Geochemistry Science Center (GGGSC)-Plasma Lab in Denver, CO where U-Pb geochronology analyses were performed by Christopher Holm-Denoma in 2016-2017. The resulting data, excerpted from the laboratory report, are presented in this publication. All files can be downloaded from the DGGS website (http://doi.org/10.14509/30439).

Samples collected during this project, as well as laboratory sample rejects and pulps, will be stored at the DGGS Geologic Materials Center in Anchorage, Alaska.

\section{METHODS}

\section{Sample Collection}

Fresh, unweathered samples from surface bedrock outcrops were collected by DGGS field geologists; samples of representative rock types and important intrusive bodies were prioritized for analysis. Samplelocation coordinates (in WGS84 datum) were collected using handheld Trimble Juno T5 GPS units, with typical reported accuracy of about 10 meters. Location coordinates for all dated samples are provided in an accompanying .csv file in decimal-degree format, WGS84 datum. This file also contains brief descriptions of each sample based on field observations. Major-oxide and trace-element geochemical data are published and available on the DGGS website for most of the samples for the (Tok River project: Wypych and others, 2015a, 2016; Wrangellia project: Wypych and others, 2015b).

\section{Sample Preparation}

Zircon was concentrated using standard processing methods as described in Strong and Driscoll (2016), which included crushing, grinding, and sieving. The $500 \mu \mathrm{m}-44 \mu \mathrm{m}$ (standard U.S. mesh sizes 35-325) sieve fraction was then processed using a Wilfley table and a Frantz magnetic barrier laboratory separator; the nonmagnetic fraction was further processed using heavy liquid (Methylene Iodide; density $=3.32 \mathrm{~g} / \mathrm{cm}^{3}$ ). The concentrated non-magnetic, heavy mineral $\left(>3.32 \mathrm{~g} / \mathrm{cm}^{3}\right.$ density) fraction was either hand-picked (for igneous grain mounting) or poured (for detrital zircon samples) onto two-sided tape and mounted in epoxy. Zircon in epoxy was ground to approximately half-width of the grains to expose internal portions of the grains. The zircon grains were imaged using transmitted and reflected light as well as scanning electron microscope-cathodoluminescence imaging to reveal inclusions, cracks, and growth zoning. 


\section{U-Pb Analytical Methods}

Zircon U-Pb analyses were conducted at the U.S. Geological Survey, Geology, Geophysics, and Geochemistry Science Center (GGGSC)-Plasma Lab in Denver, Colorado. C.S Holm-Denoma analyzed zircon crystals with Laser Ablation-Inductively Coupled Plasma-Mass Spectrometry (LA-ICP-MS) using a $\mathrm{Nu}$ Instruments AttoM ${ }^{\mathrm{Tm}}$ high-resolution, sector-field ICP-MS. Zircon were ablated with a Photon Machines Excite $^{\text {Tx }} 193 \mathrm{~nm}$ ArF excimer laser in spot mode (150-200 total bursts) with a repetition rate of $5 \mathrm{~Hz}$, laser energy of $\sim 3 \mathrm{~mJ}$, and an energy density of $\sim 4.11 \mathrm{~J} / \mathrm{cm}^{3}$. The rate of helium gas flow to the HelEx cell of the laser was $0.6 \mathrm{~L} /$ minute and make-up Argon gas $(\sim 0.2 \mathrm{~L} /$ minute $)$ was added to the sample stream prior to its introduction into the plasma. As suggested by Hu and others (2008), nitrogen with flow rate of $5.5 \mathrm{~mL} / \mathrm{minute}$ was added to the sample stream, which allowed for significant reduction in $\mathrm{ThO}+/ \mathrm{Th}+(<0.5$ percent $)$ and improved the ionization of refractory Thorium. The laser spot sizes for zircon were $\sim 25 \mu \mathrm{m}$ in diameter. With the magnet parked at a constant mass, the flat tops of the isotope peaks were measured at the following masses by rapidly deflecting the ion beam: ${ }^{202} \mathrm{Hg},{ }^{204}(\mathrm{Hg}+\mathrm{Pb}),{ }^{206} \mathrm{~Pb},{ }^{207} \mathrm{~Pb},{ }^{208} \mathrm{~Pb},{ }^{232} \mathrm{Th},{ }^{235} \mathrm{U}$, and ${ }^{238} \mathrm{U}$ with a 30-second on-peak background measured before each 30 -second analysis. Raw data were reduced off-line using the Iolite $^{\mathrm{Tm}} 2.5$ program (Paton and others, 2011) to subtract on-peak background signals, correct for U-Pb downhole fractionation, and normalize the instrumental mass bias using external mineral standard reference materials, the ages of which have previously been determined by Isotopic Dilution-Thermal Ionization Mass Spectrometry (ID-TIMS). Ages are corrected by standard-sample bracketing with the primary zircon standard Temora2 (417 Ma; Black and others, 2004), secondary standard Plešovice (337 Ma; Sláma and others, 2008), and in-house standard WRP-63-08 (1707 Ma; Wayne Premo, personal commun., 2016). Reduced data were compiled and interpreted using Isoplot 4.15 (Excel version of the procedure explained in version 3.75 manual; Ludwig, 2012).

\section{RESULTS AND DISCUSSION}

Results are summarized in table 1 , and a summary table and detailed data tables are included in the accompanying data-distribution file set. All uncertainties are reported at the $2-\sigma$ level. $\mathrm{U}-\mathrm{Pb}$ age concordance filtering was used to assess whether each analysis was relatively concordant, or possibly subject to $\mathrm{Pb}-\mathrm{loss}$ events, mineral inclusions, or metamorphic rims. For detrital zircon samples, a discordance $\left({ }^{206} \mathrm{~Pb} /{ }^{238} \mathrm{U}\right.$ age versus ${ }^{207} \mathrm{~Pb} /{ }^{206} \mathrm{~Pb}$ age ratio) filter was applied (\% discordant $\left.=\left(1-\left({ }^{206} \mathrm{~Pb} /{ }^{238} \mathrm{U} \text { age } /{ }^{207} \mathrm{~Pb} /{ }^{206} \mathrm{~Pb} \text { age }\right)\right)^{\star} 100\right)$ where samples with greater than 15 percent discordance (or values more negative than -5 percent) were excluded from probability density plots. Discordance for igneous analyses is usually filtered at a $5 \%$ difference between two isotope ratio ages. However, in cases of complex zircon systematics (e.g. Pb-loss or common-Pb in zircon) analyses that show evidence of $\mathrm{Pb}$-loss or common- $\mathrm{Pb}$ are excluded from concordia and/or weighted mean plots. Exclusion of analyses are noted in data tables. Complex or low-zircon-yield samples were sometimes spot analyzed more than once on a single grain. 
Table 1. Summary table of sample locations and preferred ages, where applicable. TuffZirc age determined using the TuffZirc age-extraction routine in Isoplot 4.15 (Ludwig, 2012). Location data in WGS84 datum.

\begin{tabular}{|c|c|c|c|c|c|c|c|}
\hline $\begin{array}{c}\text { Sample } \\
\text { Number }\end{array}$ & Latitude & Longitude & $\begin{array}{c}\text { Preferred } \\
\text { Age }(\mathbf{M a})\end{array}$ & $\begin{array}{c}\text { Age Error } \\
\mathbf{( 2 \sigma )}\end{array}$ & MSWD & Preferred Age Type & $\begin{array}{c}\text { Measurements } \\
\text { Used/Total } \\
\text { Measurements }\end{array}$ \\
\hline 15KS048 & 63.0589 & -143.6336 & & & & detrital zircon & \\
\hline 15AW014 & 63.1928 & -143.6802 & & & & detrital zircon & \\
\hline 15LF060 & 62.9797 & -143.3098 & 49.7 & \pm 2.4 & 0.57 & intercept & $4 / 4$ \\
\hline 15KS006 & 63.1461 & -143.5846 & & & & no preferred age & $19 / 19$ \\
\hline 15ET135 & 62.8621 & -147.5947 & 134.9 & $+2.1 /-0.7$ & & TuffZirc age & $11 / 30$ \\
\hline 15AW008 & 63.1984 & -143.6644 & 363.3 & \pm 2.4 & 1.2 & weighted mean & $26 / 30$ \\
\hline 15DR027 & 63.1843 & -143.2896 & 367.2 & \pm 2.8 & 4.3 & weighted mean & $23 / 29$ \\
\hline 15LL006 & 63.2061 & -143.3704 & 65.74 & \pm 0.55 & 0.91 & weighted mean & $29 / 30$ \\
\hline 15DR129 & 63.3276 & -146.3101 & 301.8 & \pm 2.7 & 1.14 & weighted mean & $16 / 30$ \\
\hline 15LF304 & 63.3368 & -146.2358 & 159.6 & \pm 1.1 & 1.19 & weighted mean & $19 / 30$ \\
\hline
\end{tabular}

\section{Detrital zircon samples from the Tok River area}

\section{AW014-Schist}

This sample is from the amphibolite-facies gneiss and schist unit (Dg) of Sicard and others (2017), correlative to the Macomb unit of Dashevsky and others (2003). It is composed of fine-grained schist that is light gray, with trace weathering, to dark gray with a yellowish tinge. It is foliated and schistose with a grain size of 0.1 to $0.5 \mathrm{~mm}$. The mineralogy is approximately 30 percent feldspar, 20 percent quartz, 30 percent unidentified mafic minerals, and 10 percent biotite. Foliation is weak with layering composed of biotite and mixed mafic and felsic minerals and is $0.5-\mathrm{mm}$ to $1-\mathrm{mm}$ thick. 
One hundred and twenty individual grains were analyzed. This sample yielded 91 zircon grain analyses that met discordance cutoff criteria. The largest probability peak is at $\sim 1170 \mathrm{Ma}$ and secondary peaks at $\sim 1060$ $\mathrm{Ma}, \sim 1875 \mathrm{Ma}$, and Archean peaks at $2555 \mathrm{Ma}$ and $2850 \mathrm{Ma}$ (fig. 1).

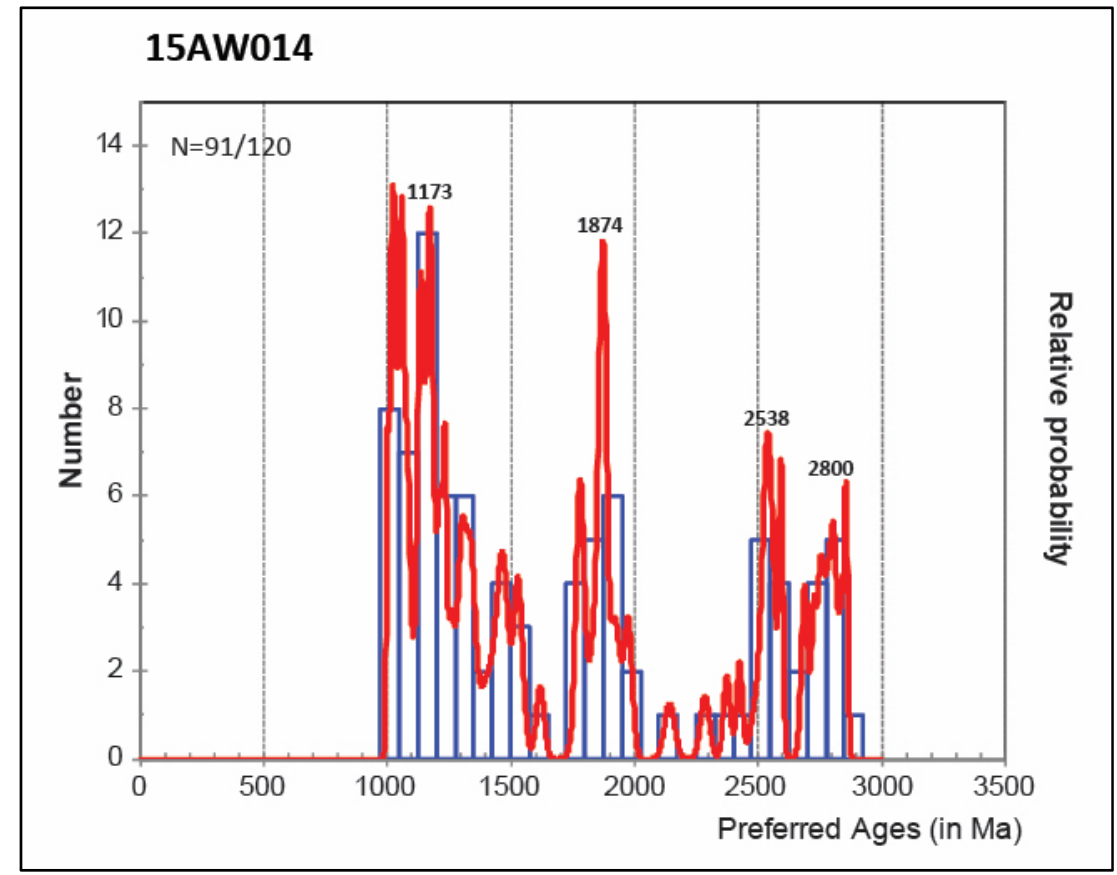

Figure 1.U-Pb probability density plot for sample 15AW014.

\section{KS048-Quartzite}

The sample is of quartzite, unit MDq of Sicard and others (2017). This pink to gray, medium-grained quartzite contains at least 90 percent quartz, about 5 percent calcite, 2 percent muscovite, and 3 percent graphite. Muscovite forms discontinuous foliation planes, and brown calcite veins are folded throughout the unit. This unit is massive and very hard and displays outcrop-scale folding. 
This sample yielded 88 of 120 analyses that met discordance cutoff requirements. There is a large broad age peak spanning $2000-1700 \mathrm{Ma}$ (53 total analyses fall within that range) with the highest probability at 1860 Ma. Other, smaller peaks occur around 1100-1000 Ma, 2340, and $2730 \mathrm{Ma}$ (fig. 2).

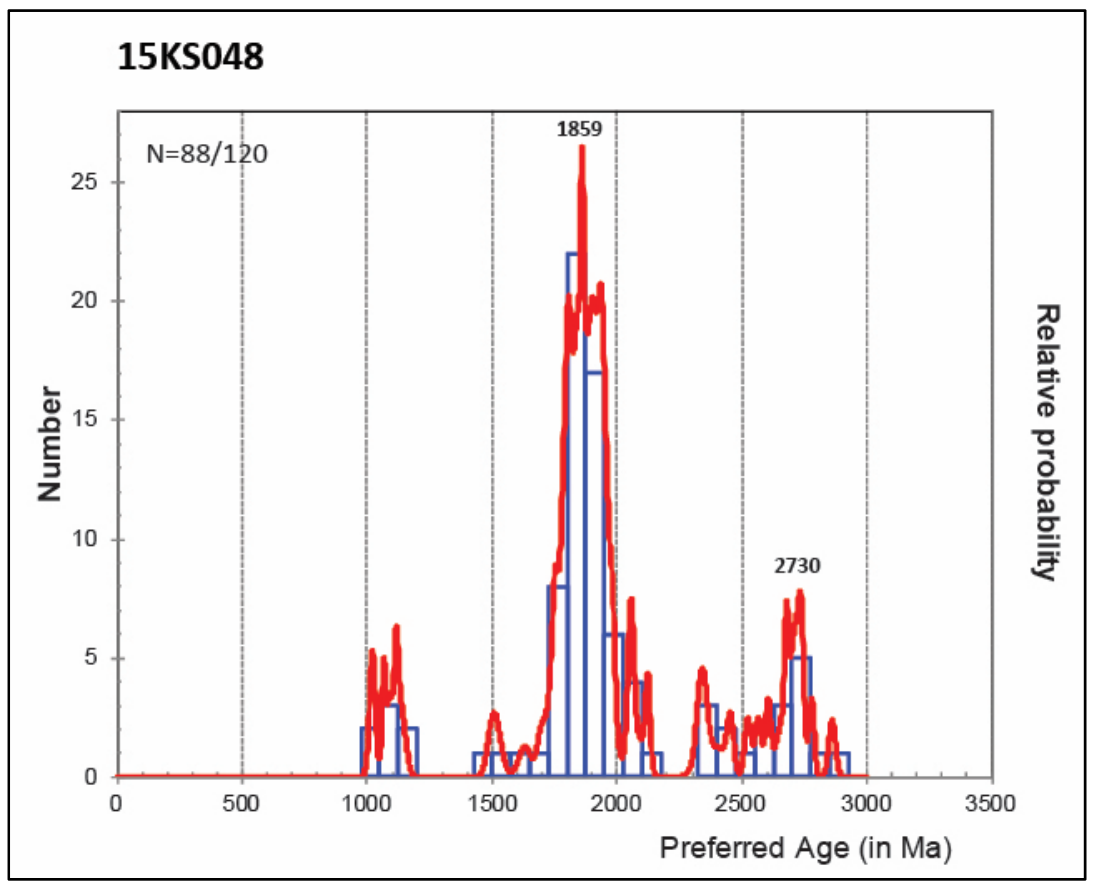

Figure 2. U-Pb probability density plot for sample 15KS048.

\section{Igneous crystallization-age samples from the Tok River area}

\section{lgneous rocks}

\section{LL006-Granodiorite}

This sample is from a granodiorite and granodiorite porphyry intrusion in the Clearwater Creek area (unit $\mathrm{Kgd}$; Sicard and others, 2017). It is a medium-grained granodiorite, gray and white, with about 50 percent feldspar, 35 percent mafic minerals, and 10 percent quartz. The outcrop shows well-developed jointing that forms sheets about $10-\mathrm{cm}$ thick. Pervasive clay alteration or weathering appears throughout the outcrop.

This sample yielded a weighted-average age of $65.74 \pm 0.55 \mathrm{Ma}$ (fig. 3A) and a concordia age of $65.88 \pm$ $0.65 \mathrm{Ma}$ (fig. 3B). Both ages are within error of each other, but the weighted-average age has a mean square weighted deviation $(\mathrm{MSWD})=0.91$, whereas the concordia age has a $\mathrm{MSWD}=13$, so we prefer the weightedaverage age. 


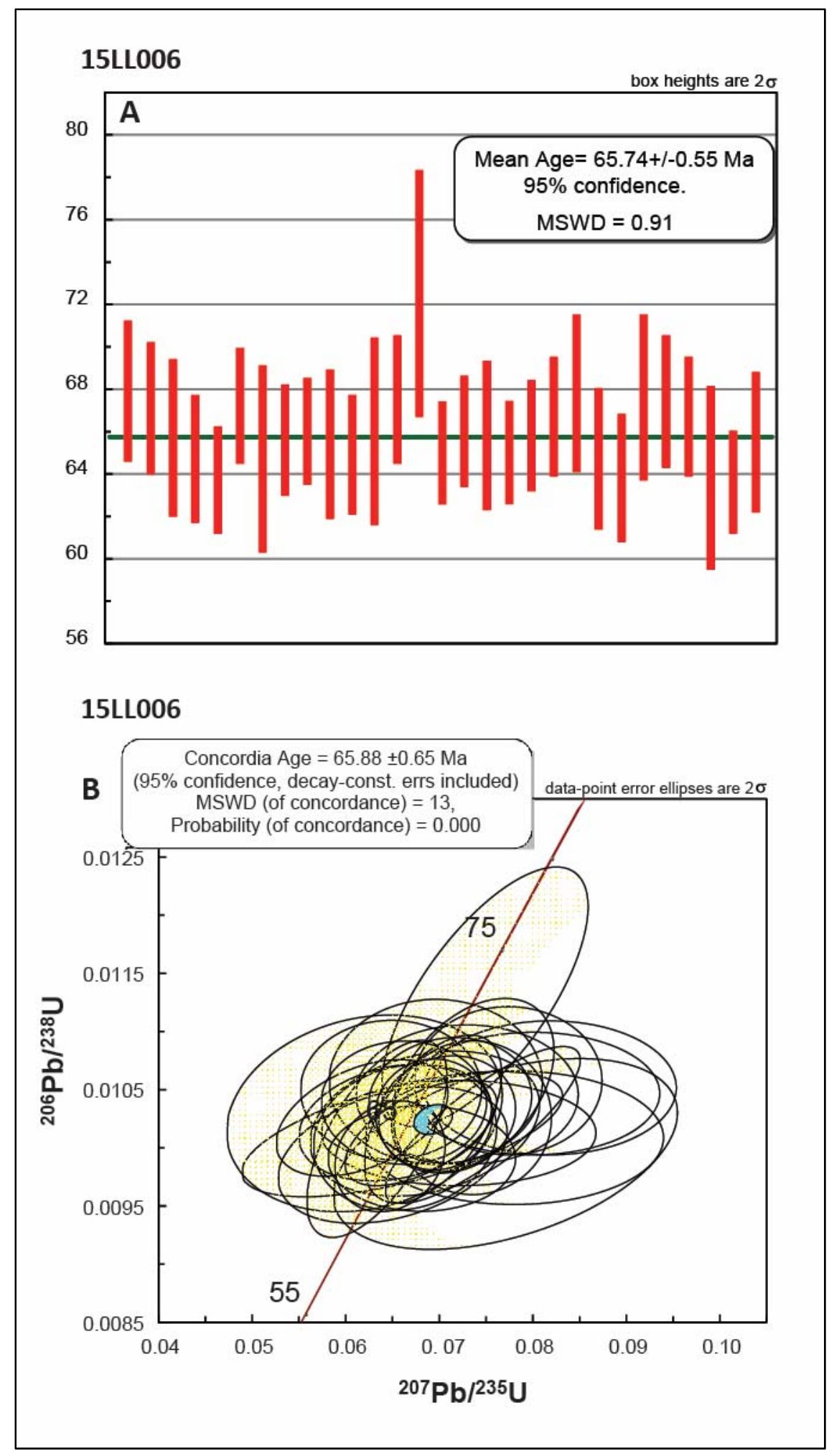

Figure 3. U-Pb plots for sample 15LL006. A. Weighted-average age diagram; bars reflect age errors at the 2-sigma level. B. Concordia diagram; ovals reflect errors at the 2 -sigma level. 


\section{LF060-Diorite}

Medium- to coarse-grained, brown, and weathering to greenish-gray. Textures are hypidiomorphic and seriate, with grain size in outcrop ranging from 1- to $10-\mathrm{mm}$, and nearby float containing some larger crystals. This sample is composed of about 40 percent elongate hornblende, 10 percent biotite, and about 50 percent interstitial plagioclase. Blades of hornblende appear random to trachytoidal, and there is trace weathering.

The sample yielded a weighted-average age of $52.9 \pm 2.7 \mathrm{Ma}$ (fig. $4 \mathrm{~A}$ ) and an intercept age of $49.7 \pm 2.4 \mathrm{Ma}$ (fig. 4B). The two ages are within error of each other, but the analyses (only 4 ) are slightly discordant and fall on an intercept line with low MSWD (0.57). This discordance suggests some common $\mathrm{Pb}$ is present in the zircon, but since it is linear it likely represents closed-system behavior. The intercept age is preferred, as the analyses used in the weighted-average-age determination are not corrected for common $\mathrm{Pb}$.

\section{Metamorphic rocks}

\section{AW008-Schist}

This sample is from the amphibolite-facies gneiss and schist unit (Dg) of Sicard and others (2017), correlative to the Macomb unit of Dashevsky and others (2003). It is green with white layers, rusty-colored weathering, foliated, and schistose. Its mineral constituents are 20 percent euhedral amphibole, 30 percent subhedral feldspar, 30 percent quartz, and 10 percent muscovite. The minerals are equigranular, sugary, and are around 1 to $2 \mathrm{~mm}$ in diameter. Amphibole with biotite and muscovite form mafic layers, whereas quartz and feldspar form felsic layers. The felsic layers are around 2- to 3-mm thick, mafic layers are around 1-mm thick, and some quartz boudins run through the package, averaging 10 - to $15-\mathrm{cm}$ thick.

The weighted-average age from this sample of $363.3 \pm 2.4 \mathrm{Ma}$ (fig. 5A), and the concordia age of 365.7 $\pm 2.4 \mathrm{Ma}$ are within error of each other (fig. $5 \mathrm{~B}$ ). The weighted-average age has a MSWD=1.2 whereas the concordia age has a MSWD $=12$, therefore we prefer the weighted-average age.

\section{DR027-Orthogneiss}

This sample is from the quartzite and quartz schist (MDq) of Sicard and others (2017); as defined, a minor constituent of this unit is felsic metavolcanic rock. The sample is fine-grained orthogneiss, orange to tan on weathered surfaces and tan to white on fresh surfaces, with approximately 40 percent quartz, 40 percent feldspar, 20 percent biotite, and trace chlorite. Very thin layers of mica define the foliation, and quartz ribbons and quartz eyes appear parallel to foliation.

The weighted-average age (fig. $6 \mathrm{~A}$ ) of this sample is $367.2 \pm 2.8 \mathrm{Ma}$ (after removing the most discordant grains from the weighted-average calculation); we were unable to resolve a concordia age (fig. 6B) due to high scatter (MSWD =14). The scatter is likely due to systematic Pb-loss during geologic events that post-date crystallization. Alternatively, the data may show systematic Pb-loss at event(s) close in age (within error) to the crystallization age or multiple age populations. Visual inspection of the weighted-average data for sample 15DR027 (fig. 6A) shows the possibility of two age components. Using the Unmix tool in Isoplot (Ludwig, 2012), and assuming a 2-component mixture of ages, $374.3 \pm 2.3 \mathrm{Ma}$ and $361.6 \pm 1.6 \mathrm{Ma}$ are the resulting ages determined. This rock is assigned a Late Devonian age.

\section{KS006-Metagabbro}

This sample is from a body of Triassic(?) metagabbro (unit Trg) within quartzite (unit MDq; Sicard and others, 2017). The metagabbro is dark green, medium-grained, foliated, with grain size ranging from 1- to 4 - 
$\mathrm{mm}$ diameter. The mineralogy is approximately 60 percent amphibole, 15 percent tabular interstitial plagioclase, 15 percent pyroxene, 10 percent chlorite, and trace biotite. Iron oxide and calcite are present on fractures; calcite is also present in veins. 


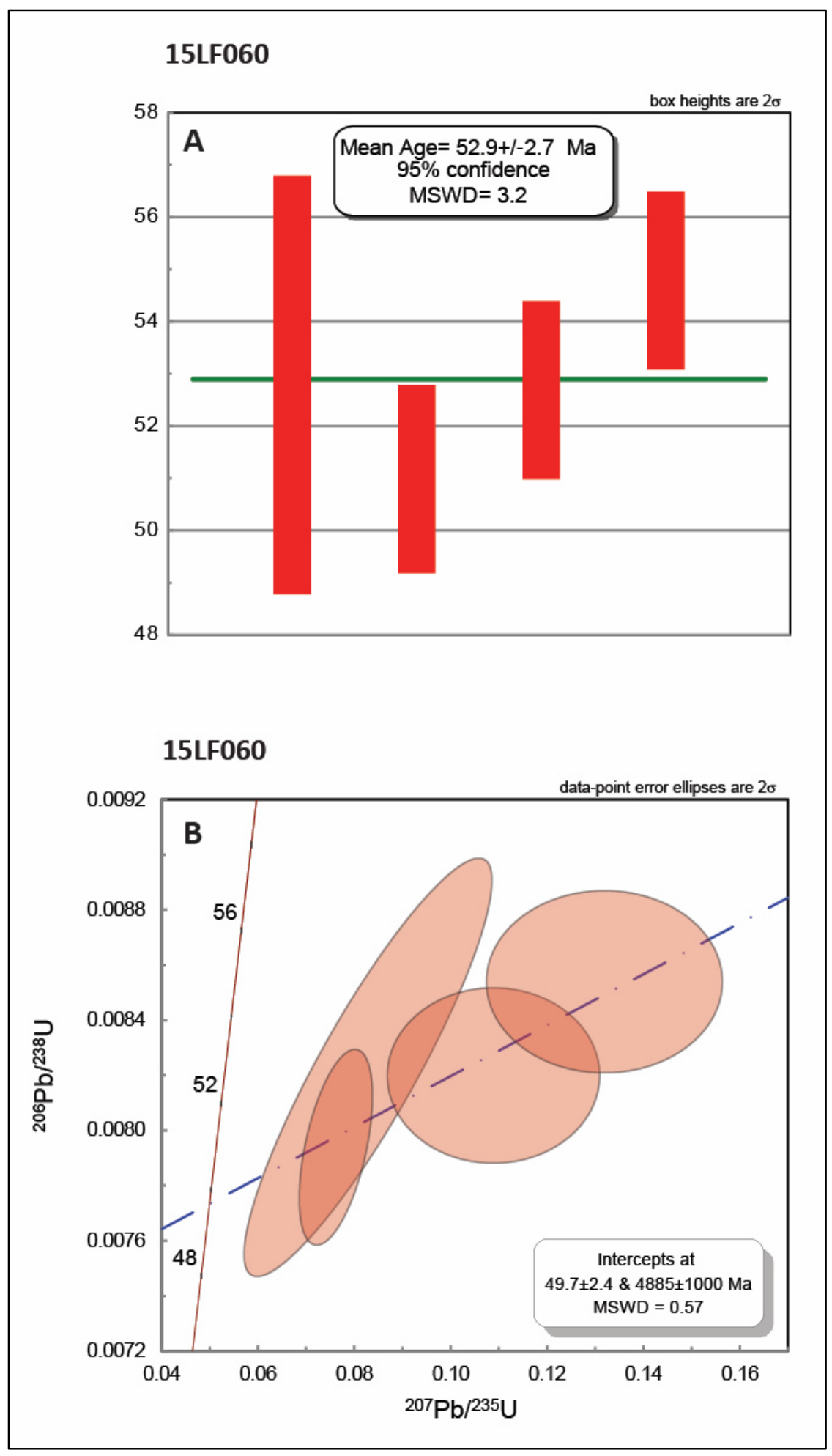

Figure 4. U-Pb plots for sample 15LF060. A. Weighted-average-age diagram; bars reflect age errors at the 2-sigma level. B. Concordia diagram; ovals reflect errors at the 2-sigma level. 


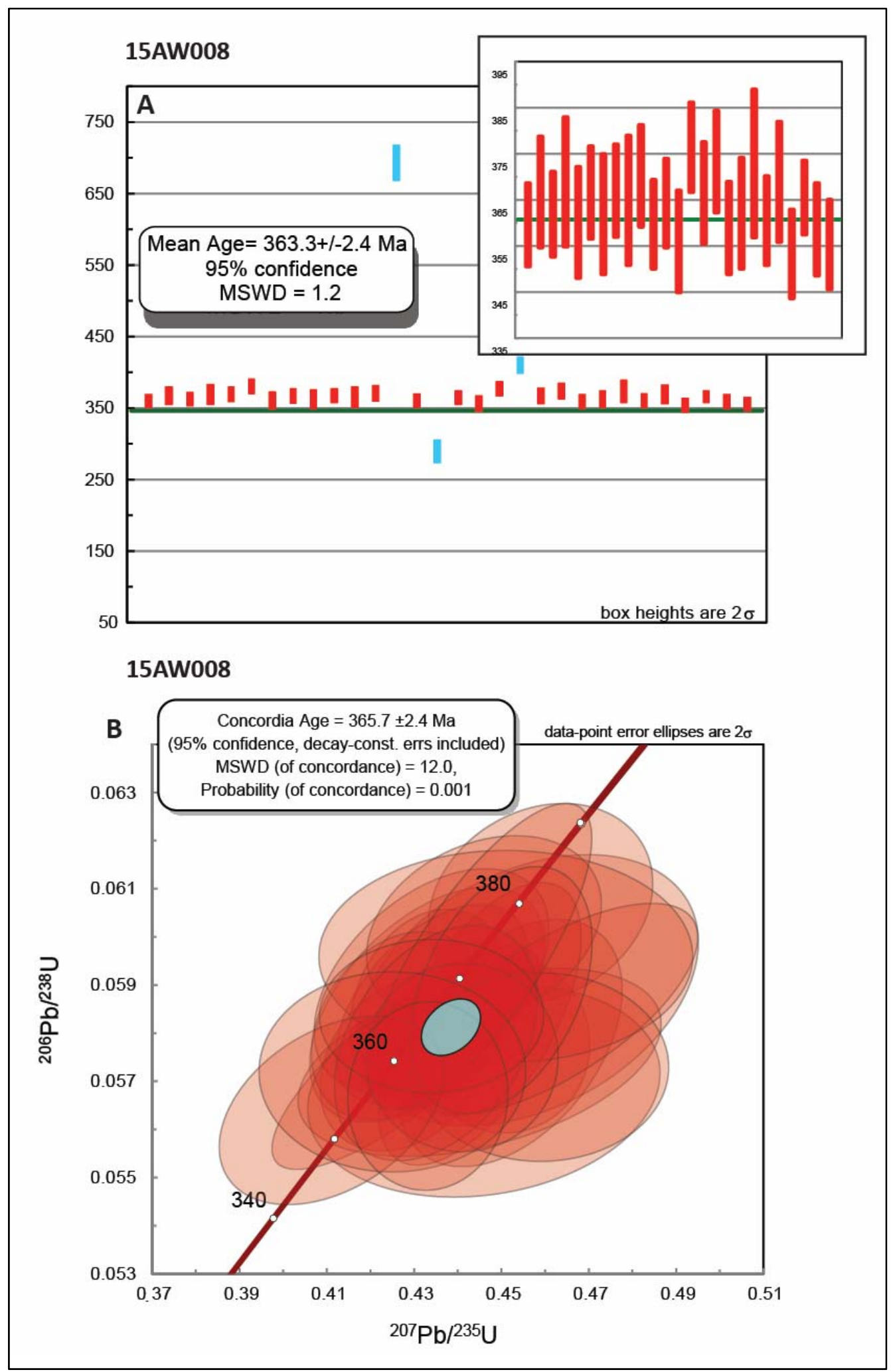

Figure 5. U-Pb plots for sample 15AW008. A. Weighted-average-age diagram; inset shows results excluding outliers. Bars reflect age errors at the 2-sigma level. B. Concordia diagram, excluding outliers; ovals reflect errors at the 2-sigma level. 


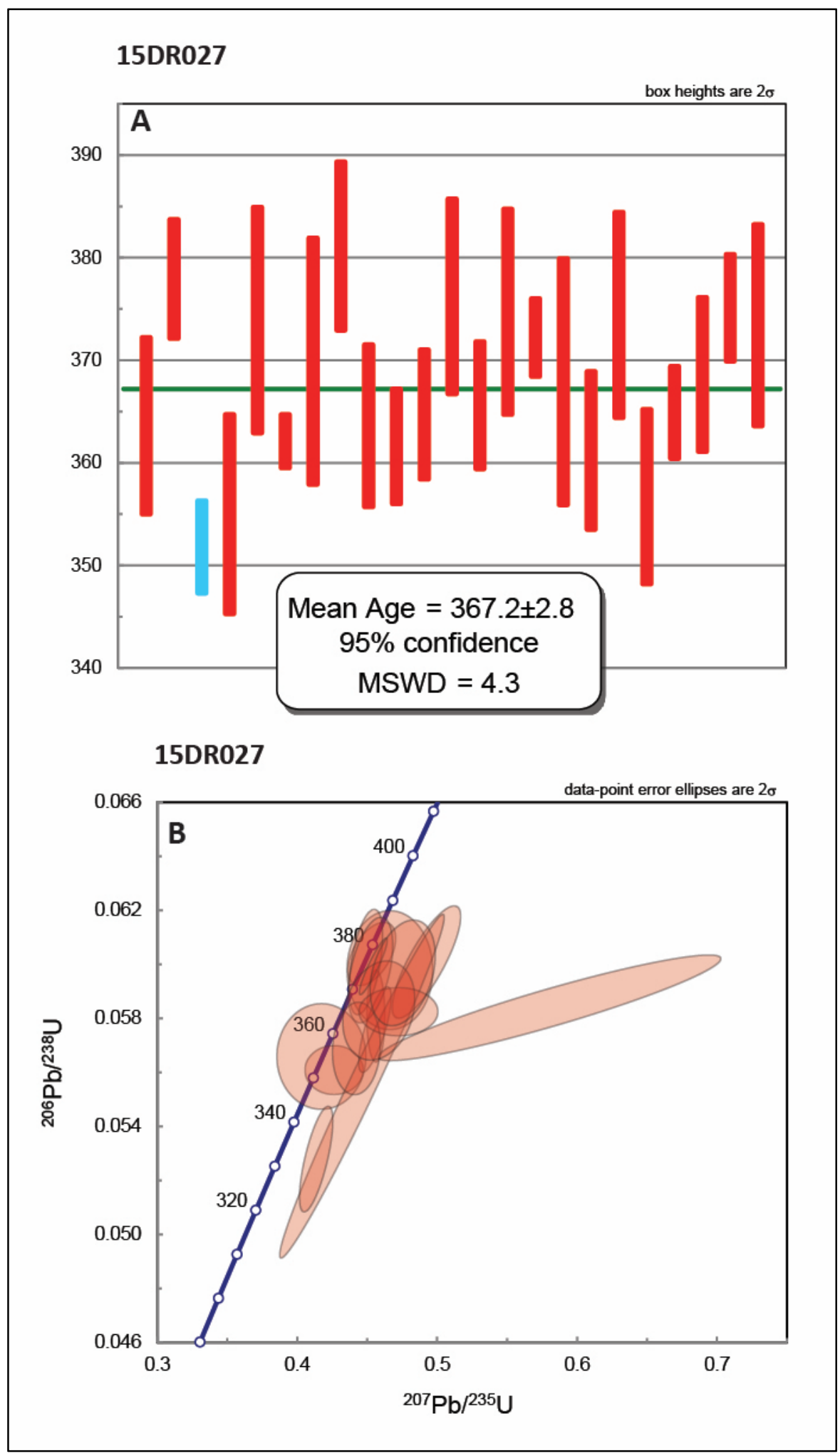

Figure 6. U-Pb plots for sample 15DR027. A. Weighted-average-age diagram; bars reflect age errors at the 2-sigma level. B. Concordia diagram; ovals reflect errors at the 2-sigma level. 
The sample yielded only 10 zircon grains, from which 18 spots were analyzed (fig. 7). The resulting relatively concordant age analyses fall within a range from $\sim 100 \mathrm{Ma}$ to $233 \mathrm{Ma}$, except for a single relatively discordant Precambrian core spot analysis on a grain that also yielded a concordant Triassic ( 222 Ma) and discordant, apparently younger than $100 \mathrm{Ma}$, spot analysis.

\section{Detrital zircon analysis of samples from Talkeetna Mountains and eastern Alaska Range}

\section{LF304B - Calcareous metagraywacke}

This sample is from a 10-cm-thick bed of calcareous metagraywacke within a metasedimentary section dominated by carbonaceous slate and phyllite (unit KJp; Twelker and others, in review). In outcrop, the sample contains rip-up clasts of fine-grained metasedimentary rock. In thin section, the sample displays a clastic, possibly cataclastic texture with about 35 percent subrounded clasts dominated by plagioclase feldspar ranging from 0.1 - to $0.5-\mathrm{mm}$ in diameter. Potassium feldspar makes up an additional 5 percent of the clasts, and another 5 percent of the rock consists of very fine-grained (50-microns-diameter) feldspar which may be volcanic lithics clasts. Phyllitic partings consist of 5 percent very fine-grained (less than 0.1 -mm-diameter) white mica, plus about 5 percent opaques likely including graphite and possibly rutile. Calcite makes up the remaining 40 percent of the rock.

While the sample appears to be a metasedimentary rock, all analyses yielded a single-age population, with a weighted-average age of $159.6 \pm 1.1 \mathrm{Ma}$, and relatively concordant analyses (fig. 8A). Due to the metasedimentary nature of the rock, we interpret this sample as a detrital zircon age with a single age population averaging ca. $160 \mathrm{Ma}$ (fig. 8B), or zircon derived from relatively close-in-age zircon-forming events (for example, volcanism spanning the age range of the analyzed zircons).

\section{Igneous crystallization-age samples from Talkeetna Mountains and eastern Alaska Range}

\section{ET135-Monzogranite}

This sample is from a medium-grained, equigranular monzogranite pluton located in the northwestern Talkeetna Mountains, mapped as unit Keg by Twelker and others (in review). The estimated modal composition is 40 percent euhedral plagioclase (0.5- to $1.5-\mathrm{mm}$ diameter); 33 percent anhedral potassium feldspar (0.5- to 5-mm diameter) overgrowing plagioclase and quartz; 25 percent quartz grains (0.5-mm diameter); 1 percent fully chloritized biotite; 1 percent apparently primary white mica as euhedral books $(0.25$ mm diameter), intergrown with potassium feldspar; less than 1 percent epidote. Whole-rock geochemistry indicates this intrusion is a peraluminous granite of volcanic arc affinity (Wypych and others, 2015b).

Ages of zircons determined for this sample form three separate populations. The dominant, mostcoherent population has an Early Cretaceous age of 134.9 +2.1 / -0.70 Ma (fig. 9) determined using the TuffZirc age-extraction routine in Isoplot 4.15 (Ludwig, 2012). An older population of ages ranging from 280 to $320 \mathrm{Ma}$ may reflect inheritance from Skolai arc magmatism, which occurred between 290 and $320 \mathrm{Ma}$ (Beard and Barker, 1989). Two analyses at around $80 \mathrm{Ma}$ may reflect alteration or $\mathrm{Pb}$-loss.

\section{DR129—Monzogranite}

This sample is a medium- to coarse-grained, seriate monzogranite, mapped as unit * $\mathrm{g}$ of Twelker and others (in review). The estimated modal composition is 35 percent quartz (0.25- to 1.5-mm diameter); 40 percent 

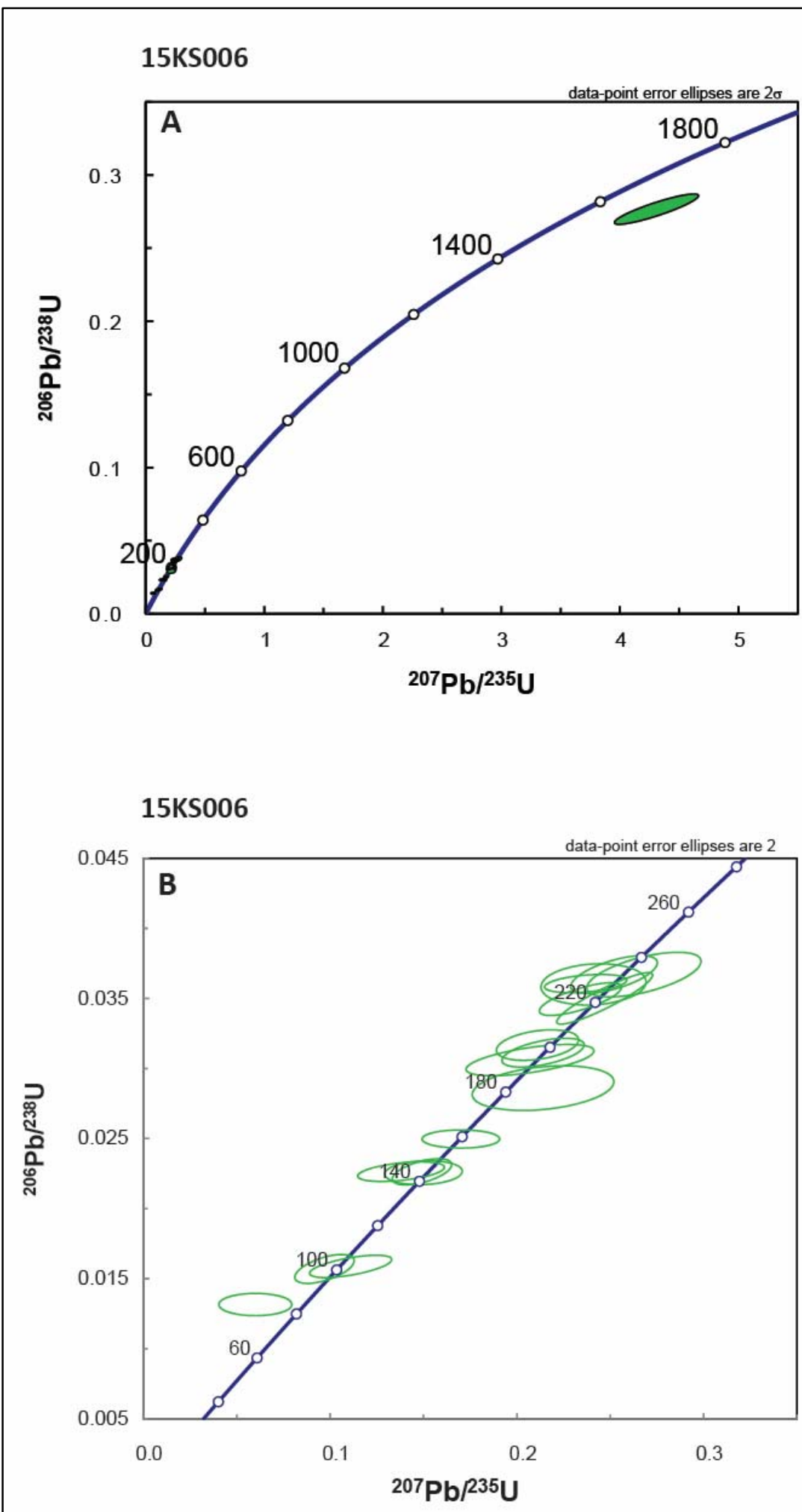

Figure 7. U-Pb plots for sample 15KS006. A. Concordia diagram for all data; ovals reflect errors at the 2-sigma level. B. Concordia diagram for Mesozoic grains; ovals reflect errors at the 2-sigma level. 


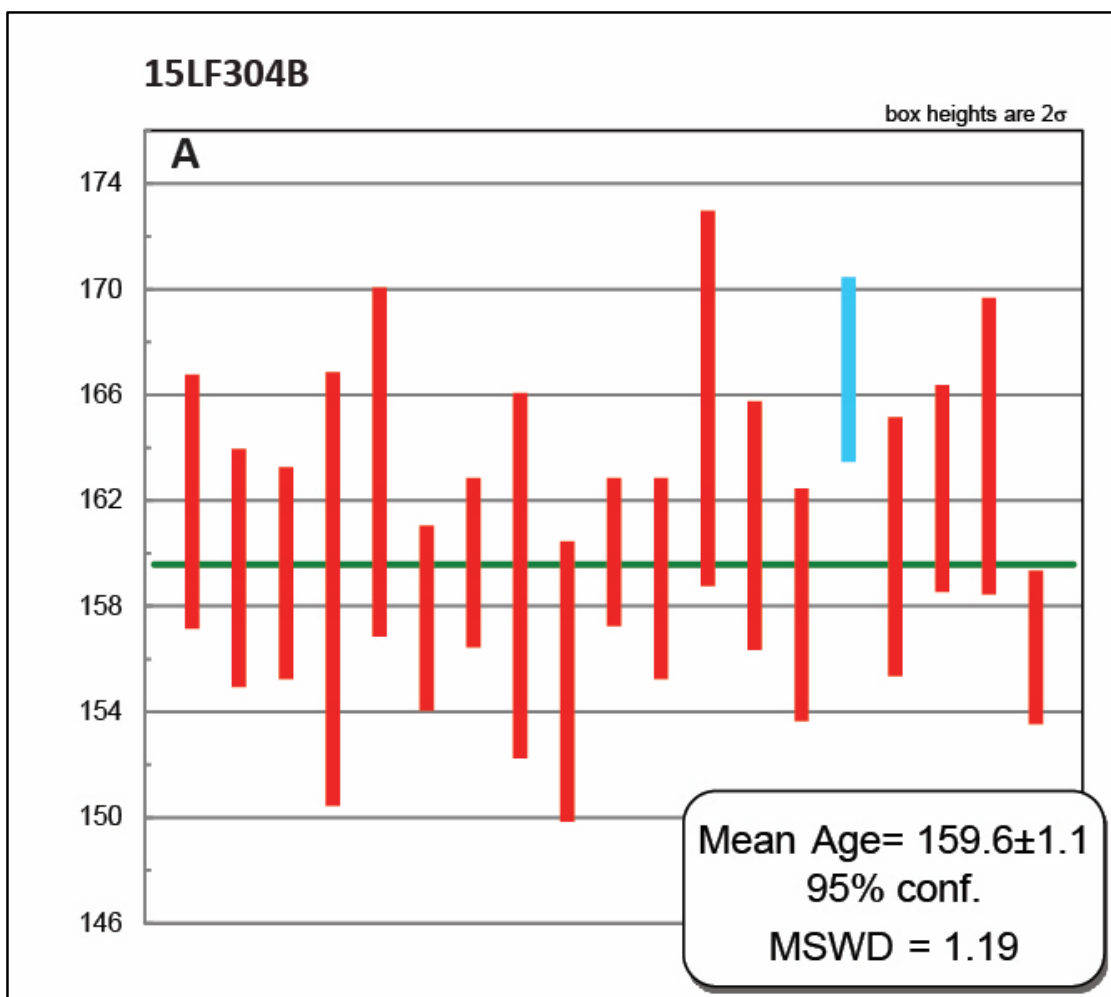

15LF304B

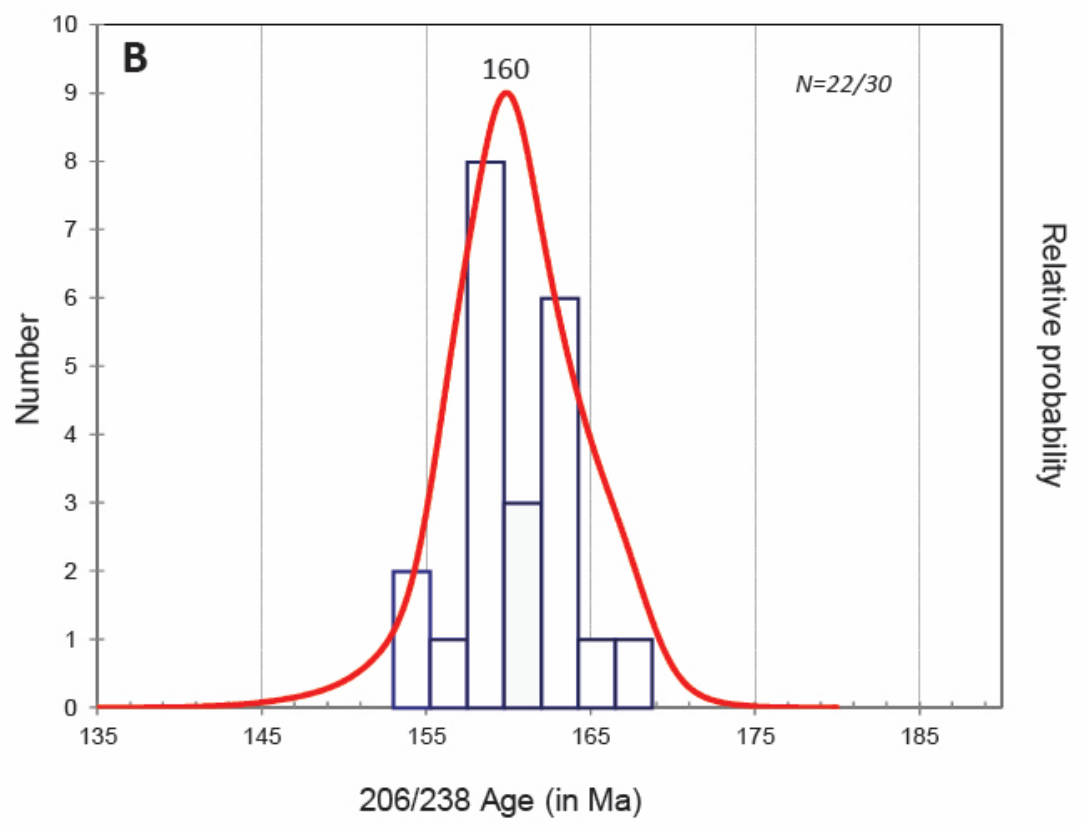

Figure 8. U-Pb plots for sample 15LF304B. A. Weighted-average-age diagram; bars reflect age errors at the 2-sigma level. B. Probability density plot. 


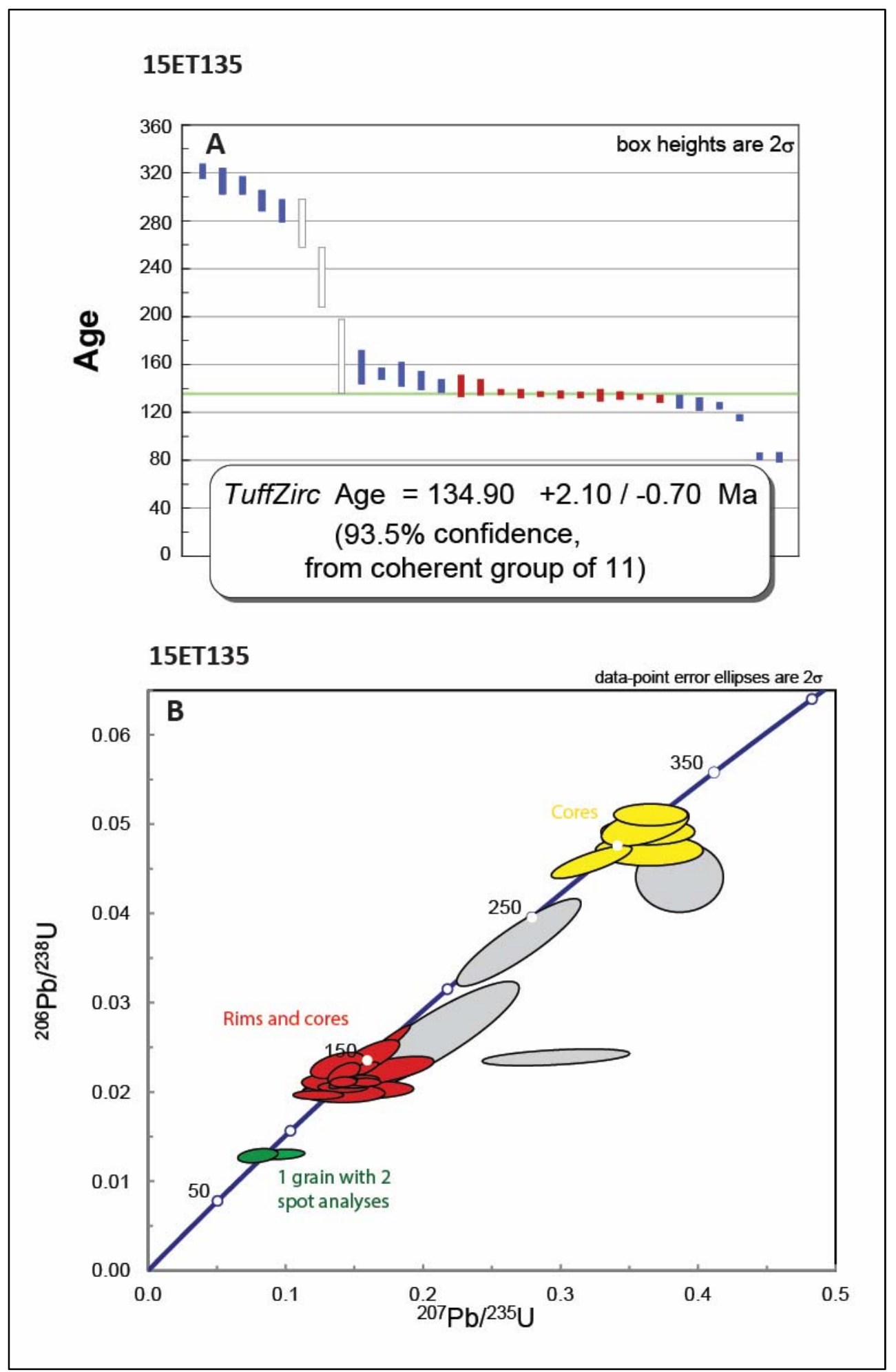

Figure 9. U-Pb plots for sample 15ET135. A. Age distribution plot for TuffZirc analysis (Ludwig, 2012). The samples selected by the age-extraction routine are shown in red. Bars reflect age errors at the 2-sigma level. B. Annotated concordia diagram; ovals reflect errors at the 2-sigma level. 
euhedral plagioclase, partially to sericite (1- to 4-mm diameter); 20 percent potassium feldspar, anhedral (2to 5-mm diameter); 2 percent biotite as (1- to 2-mm-diameter books), mostly altered to chlorite, locally to epidote and titanite; less than 1 percent hornblende. Zircon was observed as 20- to 50-micron-diamter inclusions in biotite. Whole-rock geochemistry indicates this intrusion is a peraluminous granite of volcanic arc affinity (Wypych and others, 2015b).

Zircons from this sample yield a weighted-average age of 301.8 $\pm 2.7 \mathrm{Ma}$, after removing discordant grain analyses (fig. 10A); no concordia age was determined due to excessive scatter (fig. 10B). 


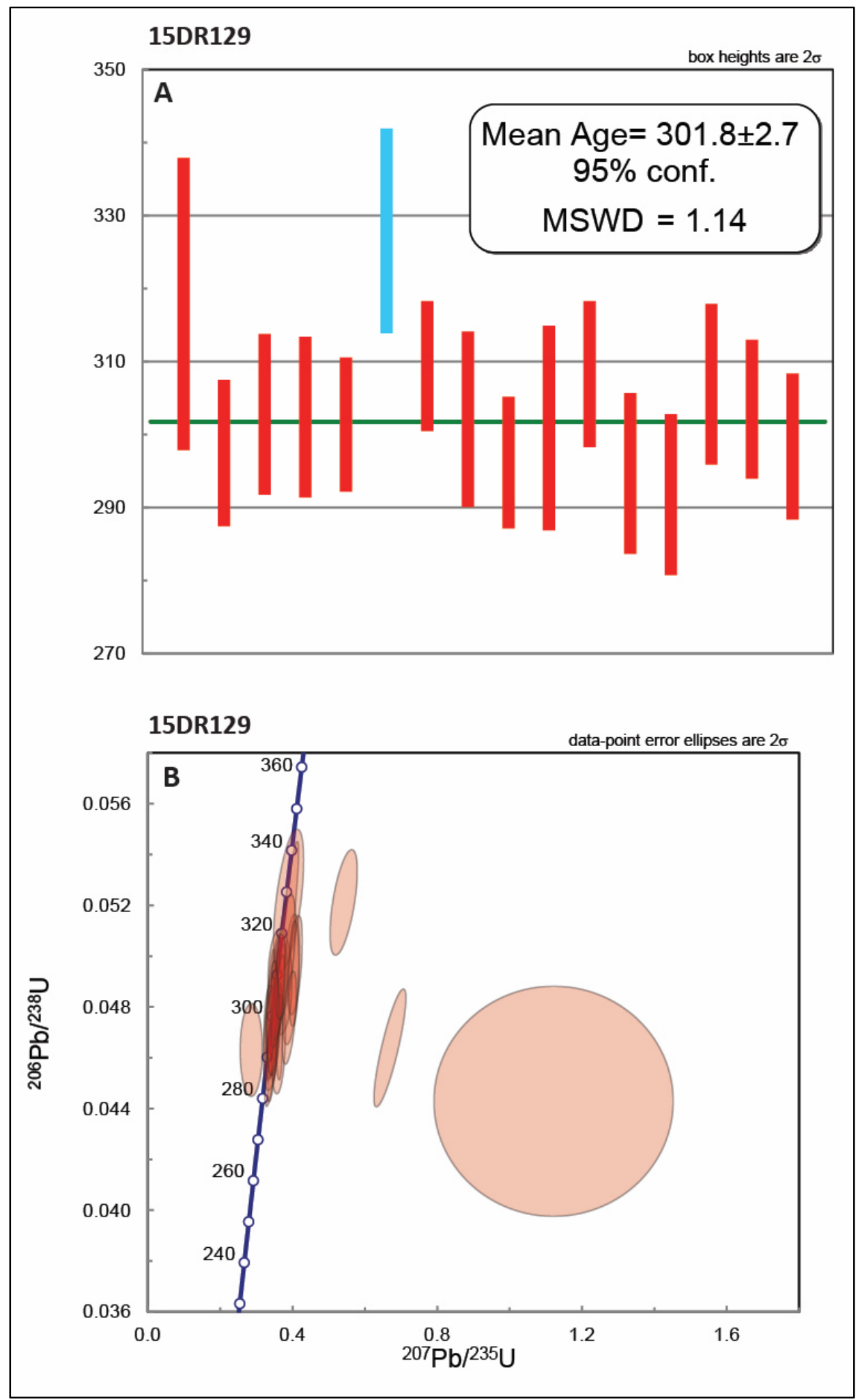

Figure 10. U-Pb plots for sample 15DR129. A. Weighted-average-age diagram; bars reflect age errors at the 2-sigma level. B. Concordia diagram; ovals reflect errors at the 2 -sigma level. 


\section{ACKNOWLEDGMENTS}

Acquisition of these data was funded through Cooperative Agreement Number 16CMFUSAGEOCHRN between the U.S. Geological Survey (USGS) and the Alaska Department of Natural Resources, Division of Geological \& Geophysical Surveys.

This project was jointly funded by the State of Alaska's Strategic and Critical Minerals Assessment project (part of DGGS's Airborne Geophysical/Geological Mineral Inventory program [AGGMI]), a USGS Mineral Resources Assessment Grant G16AS00003, and the USGS National Cooperative Geologic Mapping Program, STATEMAP component, under 2016 award number G16AC00182. The views and conclusions contained in this document are those of the authors and should not be interpreted as necessarily representing the official policies, either expressed or implied, of the U.S. Government.

We acknowledge Heidi Lingenfelter and Joe Bovee representing Ahtna, Inc., James Mery of Doyon Limited, and Mentasta Village, for providing access to private lands in the map area. Staff at the U.S. Bureau of Land Management (BLM) Glennallen Field Office and of BLM's eastern Field Office (Fairbanks) assisted us with permitting on BLM-managed lands. Field mapping and sample collection were conducted by Lawrence Freeman, Robert Gillis, Lauren Lande, Travis Naibert, Rainer Newberry, David Reioux, Karri Sicard, Evan Twelker, Melanie Werdon, Amanda Willingham, and Alicja Wypych. Much appreciated field mapping, regional geologic context, and sample-collection assistance came from Samuel Dashevsky and James V. Jones. Sarah Bala and Thomas Strong assisted with sample preparation and processing.

Any use of trade, firm, or product names is for descriptive purposes only and does not imply endorsement by the U.S. Government.

\section{REFERENCES}

Beard, J.S., and Barker, Fred, 1989, Petrology and tectonic significance of gabbros, tonalites, shoshonites, and anorthosites in a late Paleozoic arc-root complex in the Wrangellia terrane, southern Alaska: The Journal of Geology, v. 97, n. 6, p. 667-683. http://doi.org/10.1086/629351

Benowitz, J.A., Sicard, K.R., Naibert, T.J., and Layer, P.W., 2017, ${ }^{40} \mathrm{Ar} /{ }^{39} \mathrm{Ar}$ data from the Tok River area, Tanacross A-5 and A-6 quadrangles and adjoining areas, eastern Alaska Range: Alaska Division of Geological \& Geophysical Surveys Raw Data File 2017-5, 26 p. http://doi.org/10.14509/29727

Black, L.P., Kamo, S.L., Allen, C.M., Davis, D.W., Aleinikoff, J.N., Valley, J.W., Mundil, Roland, Campbell, I.H., Korsch, R.J., Williams, I.S., and Foudoulis, Chris, 2004, Improved ${ }^{206} \mathrm{~Pb} /{ }^{238} \mathrm{U}$ microprobe geochronology by the monitoring of a trace-element-related matrix effect; SHRIMP, ID-TIMS, ELAICP-MS and oxygen isotope documentation for a series of zircon standards: Chemical Geology, v. 205, p. 115-140.

Dashevsky, S.S., Schaefer, C.F., and Hunter, E.N., 2003, Bedrock geologic map of the Delta mineral belt, Tok mining district, Alaska: Alaska Division of Geological \& Geophysical Surveys Professional Report 122, 122 p., 2 sheets, scale 1:63,360. http://doi.org/10.14509/2923

$\mathrm{Hu}$, Zhaochu, Gao, Shan, Liu, Yongsheng, Hu, Shenhong, Chen, Haihong, and Yuan, Honglin, 2008, Signal enhancement in laser ablation ICP-MS by addition of nitrogen in the central channel gas: Journal of Analytical Atomic Spectrometry, v. 23, p. 1093-1101. 
Illig, Peter., and Newberry, R.J., 2015, Amphibole Au-Cu skarn and massive sulfide replacement at the Peak deposit, eastern interior, Alaska, in Proceedings, PACRIM 2015 Congress (Skarn and Replacement Deposits chapter): Melbourne, The Australasian Institute of Mining and Metallurgy, p. 415-422. Ludwig, K.R., 2012, Isoplot 3.75, A geochronological toolkit for Microsoft Excel: Berkeley Geochronology Center Special Publication, no. 5., 75 p.

Paton, Chad, Hellstrom, John, Paul, Bence, Woodhead, Jon, and Hergt, Janet, 2011, Iolite: Freeware for the visualisation and processing of mass spectrometric data: Journal of Analytical Atomic Spectrometry, v. 26, p. 2508-2518.

Sláma, Jiří, Kosler, Jan, Condon, D.J., Crowley, J.L., Gerdes, Axel, Hanchar, J.M., Horstwood, M.S.A., Morris, G.A., Nasdala, Lutz, Norberg, Nicholas, Schaltegger, Urs, Schoene, Blair, Tubrett, M.N., and Whitehouse, M.J., 2008, Plesovice zircon-A new natural reference material for U-Pb and Hf isotopic microanalysis: Chemical Geology, v. 249, n. 1-2, p. 1-35.

Sicard, K.R., Naibert, T.J., Hubbard, T.D., Twelker, Evan, Wypych, Alicja, Werdon, M.B., Willingham, A.L., Gillis, R.J., Lande, L.L., and Newberry, R.J., 2017, Geologic map of the Tok River area, Tanacross A-5 and A-6 quadrangles, eastern Alaska Range, Alaska: Alaska Division of Geological \& Geophysical Surveys, Preliminary Interpretive Report 2017-3, 1 sheet. http://doi.org/10.14509/29722

Strong, T.R., and Driscoll, R.L., 2016, A process for reducing rocks and concentrating heavy minerals: U.S. Geological Survey Open-File Report 2016-1022, 16 p., http://dx.doi.org/10.3133/ofr20161022.

Twelker, Evan, Newberry, R.J., Wypych, Alicja, Sicard, K.R., Naibert, T.J., in press, Mineral occurrences in the Tok River area, eastern Alaska: Alaska Division of Geological \& Geophysical Surveys Report of Investigation series report

Twelker, Evan, Waldien, T.S., Newberry R.J., Freeman, L.K., Sicard, K.R., Lande, L.L., Wypych, Alicja, Reioux, D.A., and Bachmann, E.N., in review, Bedrock geologic map of the eastern Denali Highway area, Mount Hayes, Healy, and Talkeetna Mountains quadrangles, Alaska: Alaska Division of Geological \& Geophysical Surveys Report of Investigation series map, 1 sheet.

Wypych, Alicja, Sicard, K.R., Twelker, Evan, Freeman, L.K., Lande, L.L., and Reioux, D.A., 2015a, Majoroxide and trace-element geochemical data from rocks collected in 2015 in the Tok area, Tanacross A-5, A-6, and parts of adjacent quadrangles, Alaska: Alaska Division of Geological \& Geophysical Surveys Raw Data File 2015-15, 3 p. http://doi.org/10.14509/29517

Wypych, Alicja, Twelker, Evan, Freeman, L.K., Lande, L.L., Newberry, R.J., Reioux, D.A., and Sicard, K.R., 2015b, Major-oxide and trace-element geochemical data from rocks collected in 2015 in the Wrangellia mineral assessment area, Alaska: Alaska Division of Geological \& Geophysical Surveys Raw Data File 2015-16, 4 p. http://doi.org/10.14509/29518

Wypych, Alicja, Sicard, K.R., Gillis, R.J., Lande, L.L., Naibert, T.J., Newberry, R.J., Twelker, Evan, Werdon, M.B., and Willingham, A.L., 2016, Major-oxide and trace-element geochemical data from rocks collected in the Tok River area, Tanacross A-5 and A-6 quadrangles, Alaska in 2016: Alaska Division of Geological \& Geophysical Surveys Raw Data File 2016-9, 3 p. http://doi.org/10.14509/29685 